\title{
Groundwater flow processes and mixing in active volcanic systems: the case of Guadalajara (Mexico)
}

\author{
A. Hernández-Antonio ${ }^{1}$, J. Mahlknecht ${ }^{1}$, C. Tamez-Meléndez ${ }^{1}$, J. Ramos-Leal ${ }^{2}$, A. Ramírez-Orozco ${ }^{1}$, R. Parra ${ }^{1}$, \\ N. Ornelas-Soto ${ }^{1}$, and C. J. Eastoe ${ }^{3}$ \\ ${ }^{1}$ Centro del Agua para América Latina y el Caribe, Tecnológico de Monterrey, Monterrey, Mexico \\ ${ }^{2}$ División de Geociencias Aplicadas, Instituto Potosino de Investigación Científica y Tecnológica, San Luis Potosí, Mexico \\ ${ }^{3}$ Department of Geosciences, University of Arizona, Tucson, USA
}

Correspondence to: J. Mahlknecht (jurgen@itesm.mx)

Received: 31 December 2014 - Published in Hydrol. Earth Syst. Sci. Discuss.: 3 February 2015

Revised: 5 June 2015 - Accepted: 24 August 2015 - Published: 24 September 2015

\begin{abstract}
Groundwater chemistry and isotopic data from 40 production wells in the Atemajac and Toluquilla valleys, located in and around the Guadalajara metropolitan area, were determined to develop a conceptual model of groundwater flow processes and mixing. Stable water isotopes $\left(\delta^{2} \mathrm{H}\right.$, $\left.\delta^{18} \mathrm{O}\right)$ were used to trace hydrological processes and tritium $\left({ }^{3} \mathrm{H}\right)$ to evaluate the relative contribution of modern water in samples. Multivariate analysis including cluster analysis and principal component analysis were used to elucidate distribution patterns of constituents and factors controlling groundwater chemistry. Based on this analysis, groundwater was classified into four groups: cold groundwater, hydrothermal groundwater, polluted groundwater and mixed groundwater. Cold groundwater is characterized by low temperature, salinity, and $\mathrm{Cl}$ and $\mathrm{Na}$ concentrations and is predominantly of $\mathrm{Na}-\mathrm{HCO}_{3}$-type. It originates as recharge at "La Primavera" caldera and is found predominantly in wells in the upper Atemajac Valley. Hydrothermal groundwater is characterized by high salinity, temperature, $\mathrm{Cl}, \mathrm{Na}$ and $\mathrm{HCO}_{3}$, and the presence of minor elements such as $\mathrm{Li}, \mathrm{Mn}$ and $\mathrm{F}$. It is a mixed- $\mathrm{HCO}_{3}$ type found in wells from Toluquilla Valley and represents regional flow circulation through basaltic and andesitic rocks. Polluted groundwater is characterized by elevated nitrate and sulfate concentrations and is usually derived from urban water cycling and subordinately from agricultural return flow. Mixed groundwaters between cold and hydrothermal components are predominantly found in the lower Atemajac Valley. Twenty-seven groundwater samples contain at least a small fraction of modern water. The application of a multivariate mixing model allowed the mixing
\end{abstract}

proportions of hydrothermal fluids, polluted waters and cold groundwater in sampled water to be evaluated. This study will help local water authorities to identify and dimension groundwater contamination, and act accordingly. It may be broadly applicable to other active volcanic systems on Earth.

\section{Introduction}

Active volcanic systems are frequently accompanied by an intense hydrothermal circulation, which is controlled by the exchange of mass and energy between groundwater systems, magmatic fluids and hot rock (Goff and Janik, 2000; Di Napoli et al., 2009). The characterization of such hydrothermal systems helps on the one hand to quantify its geothermal energy potential and, on the other hand, to assess volcanicrelated risks (Di Napoli et al., 2011). Hot springs, mud deposits, fumaroles, vaporization and degassing soils give initial clues about subsurface hydrothermal conditions (Hockstein and Browne, 2000; Navarro et al., 2011). The chemical characterization of fluids and groundwater has been used as an indicator of the subsurface structure and the origin of released fluids when hydrogeological information is scarce (Henley and Ellis, 1983; Appelo and Postma, 2005). Hydrochemical data, such as high electrical conductivity (EC), high temperatures and elevated concentrations of As, $\mathrm{B}, \mathrm{Br}$, $\mathrm{Cl}, \mathrm{Cs}, \mathrm{F}, \mathrm{Fe}, \mathrm{Ge}, \mathrm{I}, \mathrm{Li}, \mathrm{Mn}, \mathrm{Mo}, \mathrm{Na}, \mathrm{Rb}, \mathrm{Sb}, \mathrm{Ta}, \mathrm{U}$ and $\mathrm{W}$ denote the presence of hydrothermal fluids in groundwater (Reimann et al., 2003; Dogdu and Bayari, 2005; Aksoy et al., 2009). However, hydrothermal volcanic systems are some- 
times difficult to analyze due to the fact that groundwater is a mixture of fluids from various sources, sometimes consisting of shallow meteoric waters from recent infiltration, seawater and hot water rising from deep hydrothermal reservoirs (Chiodini et al., 2001; Evans et al., 2002; Di Napoli et al., 2009).

The combination of different environmental tracer techniques helps elucidate the groundwater's origin, recharge, flow velocity and direction, residence or travel times, connections between aquifers, and surface and groundwater interrelations (Edmunds and Smedley, 2000; De Vries and Simmers, 2002; Appelo and Postma, 2005; Ako et al., 2013; Stumpp et al., 2014). These techniques have been applied in large semiarid to arid rift systems (Bretzler et al., 2011; Furi et al., 2011; Ghiglieri et al., 2012; Siebert et al., 2012; Panno et al., 2013; Forrest et al., 2013; Williams et al., 2013). Stable isotopes $\left({ }^{2} \mathrm{H},{ }^{18} \mathrm{O}\right)$ provide information regarding origins, recharge processes, flow paths and residence times, especially in fractured rock aquifers. Radioactive tracers like tritium $\left({ }^{3} \mathrm{H}\right)$ are relatively accessible methods to estimate groundwater ages and characterize groundwater flow systems. Relatively few studies attempt to quantify mixing between different hydrothermal and cold fluids (Forrest et al., 2013).

This study was carried out in the Atemajac-Toluquilla aquifer system (ATAS) which underlies the metropolitan area of Guadalajara, the second most populated city in Mexico ( $\sim 4$ million inhabitants), and is located in a complex neotectonic active volcanic system in the Tepic-Zacoalco Rift. Adjacent to this aquifer system is the "La Primavera" caldera. Several survey wells have been drilled up to $3 \mathrm{~km}$ deep at La Primavera to explore the potential for geothermal energy (CFE, 2000). Temperatures between 80 and $300^{\circ} \mathrm{C}$ have been registered in these wells (Verma et al., 2012), and temperatures higher than $40^{\circ} \mathrm{C}$ have been measured in adjacent springs (Sánchez-Díaz, 2007). The hydrothermal fluids and springs are characterized by high concentrations of $\mathrm{Na}$, $\mathrm{Cl}, \mathrm{SiO}_{2}, \mathrm{HCO}_{3}, \mathrm{~B}, \mathrm{~F}$, and TDS (total dissolved solids). A mixture of hydrothermal fluids and meteoric-derived water has been identified in the springs of La Primavera (SánchezDíaz, 2007). While it is assumed that this caldera influences the aquifer system underneath the metropolitan area, the proportion of hydrothermal fluids and cold water is not clear. Moreover, nitrate contamination has been related to exogenic processes induced by anthropogenic activity (GEOEXSIAPA, 2003). The diversity of the chemical results from previous studies has contributed to the difficulty in clearly evaluating the relationship between the fluids (see Results and Discussion section).

This study aims to understand the flow dynamics of groundwater by using the combination of statistical and geochemical methods. Water groups and factors that control the groundwater chemical processes were identified using a cluster and principal component analysis. Environmental tracers were used to assess chemical evolution. Mixing proportions

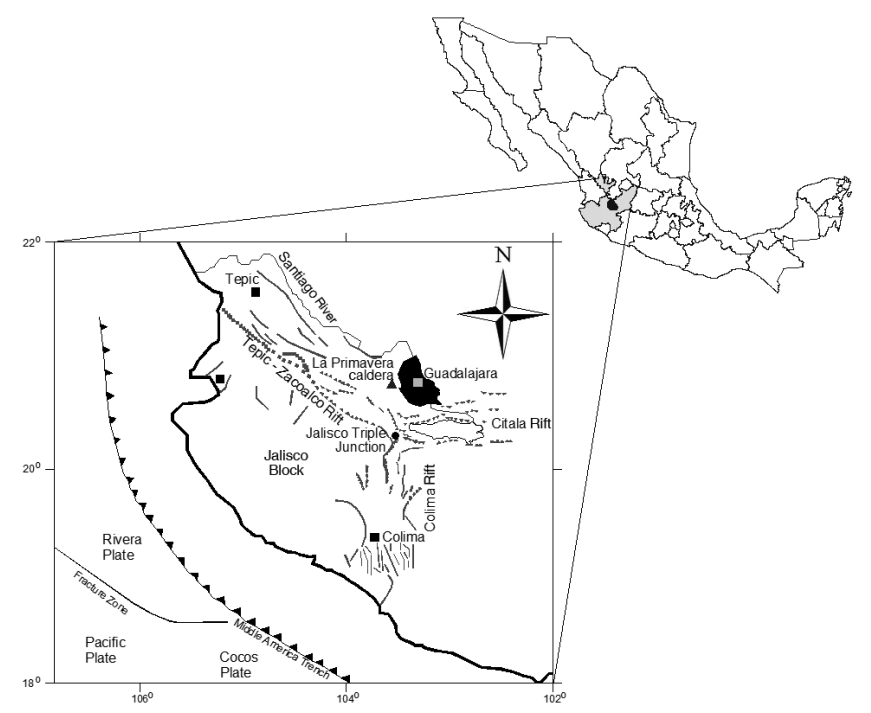

Figure 1. Location of study area (black area) in Mexico and tectonic structures of western Central Mexico.

of selected fluids in public wells were estimated by means of a multivariate mixing calculation and validated by a chloride mass balance. This study is the first of its kind to report a comprehensive understanding of groundwater flow processes below the Guadalajara metropolitan area. This information is strategic to decision makers from local water authorities regarding water resources management and may be broadly applicable to other active volcanic systems on Earth.

\section{Study area}

The study area $\left(1368 \mathrm{~km}^{2}\right)$ is situated in the central portion of the state of Jalisco (Fig. 1). It belongs to the Lerma-Santiago river system, which drains into the Pacific Ocean. According to Köppen classification, the climate in Guadalajara is considered a warm temperate climate "Cwa" (Köppen, 1936). The National Water Commission reports an average annual temperature of $20.9^{\circ} \mathrm{C}$ and an average annual precipitation of $904 \mathrm{~mm}$, occurring mostly between May and October. The mean annual evapotranspiration is $712 \mathrm{~mm}$ according to Turc's formula (CONAGUA, 2010).

\subsection{Tectonic settings}

The study area is located in the western portion of the Mexican Volcanic Belt (MVB), a $1000 \mathrm{~km}$ long volcanic arc that crosses central Mexico in an $\mathrm{E}-\mathrm{W}$ direction from the $\mathrm{Pa}-$ cific to the Atlantic Ocean. The MVB originated in the Late Miocene in response to the subduction of the Cocos and Rivera plates below the North American plate along the Middle America Trench. The belt has a composition of intermediate to silicic rocks (Alva-Valdivia et al., 2000). The western end of the MVB defines the fault-bounded crustal Jalisco 
Block (Ferrari et al., 2007; Valencia et al., 2013). The northern and eastern boundaries of this block consist of asymmetric continental rifts formed by tilted blocks with escarpments between 800 and $1000 \mathrm{~m}$ (Zárate-del Valle and Simoneit, 2005); the Tepic-Zacoalco Rift to the north runs in an NWSE direction, and the Colima Rift to the east runs in an $\mathrm{N}-\mathrm{S}$ direction; these rifts join the E-W-oriented Citala or Chapala Rift in what is known as the Jalisco Triple Junction located $60 \mathrm{~km} \mathrm{SSW}$ of the city of Guadalajara (Fig. 1). This area is a complex and active neotectonic structure that controls and regulates the development of the rift floor, limited by normal faults (Michaud et al., 2000; Zárate-del Valle and Simoneit, 2005). The Atemajac and Toluquilla valleys are located in the lower Tepic-Zacoalco Rift and are bordered by hills, volcanic cones (El Cuatro, San Martín), plateaus (Tonalá) and volcanic calderas (La Primavera), among other features (Sánchez-Díaz, 2007).

\subsection{Hydrogeological settings}

Atemajac and Toluquilla valleys consist of a relatively thin cover of Quaternary lacustrine deposits overlying a thick section of Neogene volcanic rocks including silicic domes, lava and cinder cones, lithic tuffs, basalts, ignimbrites and other pyroclastic rocks, andesites and volcanic breccia, and a basement consisting of Oligocene granite (Gutiérrez-Negrín, 1988; Urrutia et al., 2000; Campos-Enríquez et al., 2005) (Fig. 2). Hydrogeologically, these valleys are underlain by two aquifers (Fig. 3). The upper aquifer consists of alluvial and lacustrine sediments, Pleistocene precaldera pyroclastic materials (Tala Tuff) such as volcanic ash flows and lapilli, and rhyolitic domes. These sediments represent an unconfined aquifer of up to $450 \mathrm{~m}$ thickness with hydraulic conductivities ranging from $1.6 \times 10^{-7}$ to $2.0 \times 10^{-4} \mathrm{~m} \mathrm{~s}^{-1}$ and porosities from 20 to $40 \%$ (Sánchez-Díaz, 2007; CONAGUA, 2010). Groundwater recharge sources of this aquifer are rainwater and ascending vertical fluids from the lower aquifer (Gutiérrez-Negrín, 1991). Groundwater flows via faults and Toba tuffs in the direction of the central and northern portion of the study area. The lower aquifer consists of fractured andesites and basalts from Pliocene, with hydraulic conductivities and porosities ranging from $10^{-8}$ to $10^{-4} \mathrm{~m} \mathrm{~s}^{-1}$ and from 5 to $50 \%$, respectively. This semiconfined to confined aquifer has been related to geothermal fluids (Venegas et al., 1991; GEOEX-SIAPA, 2003). Groundwater of this aquifer flows preferentially in a southeastern direction (Ramírez et al., 1982).

Pumping wells are drilled in the upper aquifer. Its water table distribution is shown in Fig. 2. In the Atemajac Valley, groundwater flow direction is oriented mainly from southwest to northeast, from the topographically higher areas, towards the Santiago River, with possible recharge from normal faults west of Guadalajara (Fig. 3, Sects. I and II); while in Toluquilla the flow of groundwater circulates from northwest to southeast (Fig. 3, Sect. III) (GEOEX-SIAPA,

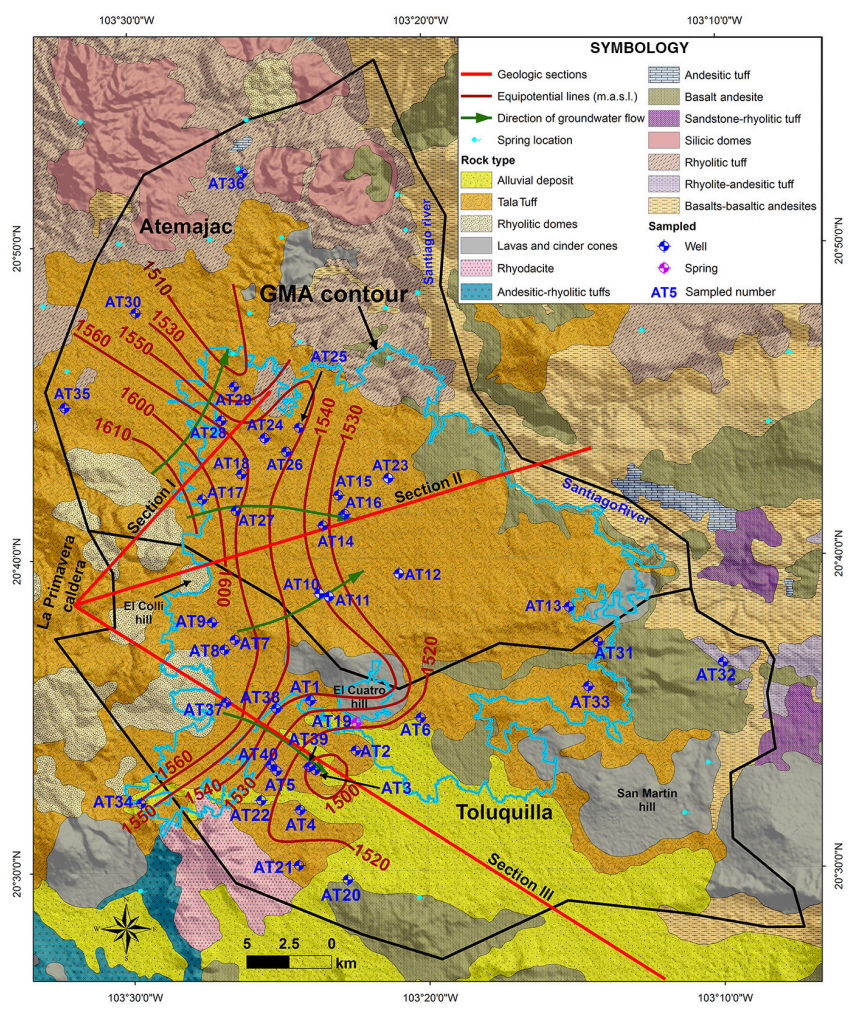

Figure 2. Surface geology, water table distribution and location of wells sampled in the study area. Note: GMA represents Guadalajara metropolitan area; the black line indicates the study area.

2003; CONAGUA, 2009). However, anthropogenic activity has been changing the flow paths, resulting in the formation of different cones of depression. The major discharge is given by well pumping activities and springs in the escarpment of the Santiago River (GEOEX-SIAPA, 2003; CONAGUA, 2009 and 2010). Due to the heavy extractions from the aquifer system, water table levels are falling up to 2.2 and $0.3 \mathrm{~m} \mathrm{yr}^{-1}$ on average in Atemajac and Toluquilla aquifers, respectively (GEOEX-SIAPA, 2003). The constructed well depth is up to $500 \mathrm{~m}$ and up to $380 \mathrm{~m}$ in the valleys of Atemajac and Toluquilla, respectively. Depth to water table reaches up to $150 \mathrm{~m}$ below ground level in the Atemajac Valley and $50 \mathrm{~m}$ in the Toluquilla Valley (GEOEX-SIAPA, 2003).

\subsection{Hydrothermal system}

The La Primavera caldera, with a diameter of $\sim 10 \mathrm{~km}$, borders the study area to the west. It is a very young (Late Pleistocene) volcanic complex underlain by a magma chamber whose top reaches a depth of $4 \mathrm{~km}$ (Verma et al., 2012). Drilling has revealed that the oldest units consist of granitic and granodioritic rocks found mainly at a depth of approximately $3000 \mathrm{~m}$. These rocks are mainly overlain by andesitic rocks approximately $1150 \mathrm{~m}$ thick. The third lithologic unit, which is approximately $100 \mathrm{~m}$ thick, consists of 


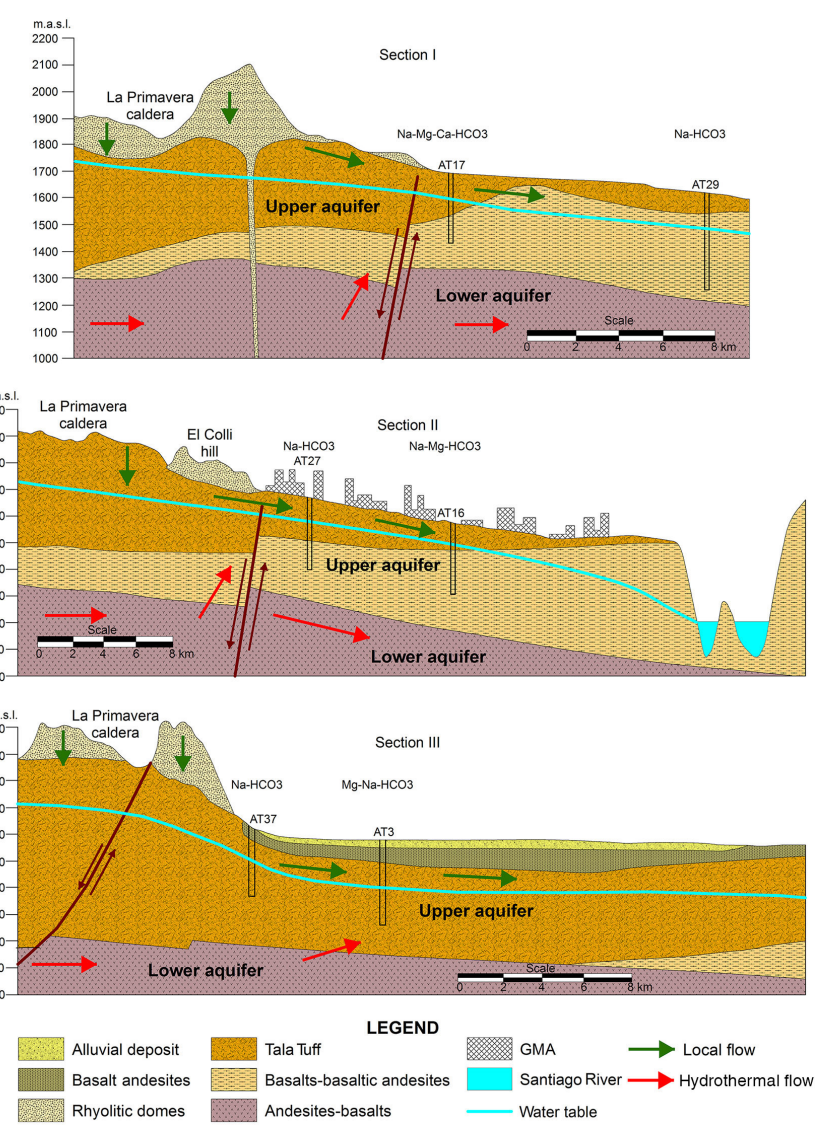

Figure 3. Cross sections indicated in Fig. 2 and considering hydrogeological settings and water types of selected wells.

rhyolites. The uppermost unit is a sequence of lithic tuffs and minor andesite with an average thickness of approximately 750 and $1000 \mathrm{~m}$, respectively (Urrutia et al., 2000; Campos-Enríquez et al., 2005; Verma et al., 2012). The system is characterized by an asymmetric structure with NWSE regional basalt lineaments that belong to the TepicZacoalco Rift and local NE-SW fractures in the upper units extending beneath Guadalajara (Alatorre-Zamora and Campos-Enríquez, 1991; Campos-Enríquez and AlatorreZamora, 1998). The temperatures, which were measured at the bottom of exploratory wells that were drilled up to $3 \mathrm{~km}$ deep, vary from 80 to $300^{\circ} \mathrm{C}$ (Verma et al., 2012). It appears that heated meteoric water ascends along fault or fracture zones to near-surface depths, and supplies springs with temperatures of $>40^{\circ} \mathrm{C}$ (Venegas et al., 1985). The hydrothermal fluids are characterized by very high concentrations of $\mathrm{Na}\left(679-810 \mathrm{mg} \mathrm{L}^{-1}\right), \mathrm{Cl}\left(865-1100 \mathrm{mg} \mathrm{L}^{-1}\right)$, $\mathrm{SiO}_{2}$ (943-1320 $\left.\mathrm{mg} \mathrm{L}^{-1}\right)$, B (75-150 $\left.\mathrm{mg} \mathrm{L}^{-1}\right)$ and TDS (2810-4065 $\mathrm{m} \mathrm{L}^{-1}$ ) (Maciel-Flores and Rosas-Elguera, 1992), while the springs are of $\mathrm{Na}-\mathrm{Cl}-\mathrm{HCO}_{3}$-type with relatively high concentrations of $\mathrm{Na}\left(260-331 \mathrm{mg} \mathrm{L}^{-1}\right)$, $\mathrm{Cl}\left(85-185 \mathrm{mg} \mathrm{L}^{-1}\right), \mathrm{SiO}_{2}\left(209-253 \mathrm{mg} \mathrm{L}^{-1}\right), \mathrm{HCO}_{3}(395-$ $\left.508 \mathrm{~m} \mathrm{~L}^{-1}\right), \mathrm{B}\left(10.8-12.3 \mathrm{mg} \mathrm{L}^{-1}\right), \mathrm{F}\left(8.5 \mathrm{mg} \mathrm{L}^{-1}\right)$ and
TDS (1071-1240 $\mathrm{mg} \mathrm{L}^{-1}$ ), indicating a mixture between hydrothermal fluids and local rainwater origin with ratios of $1: 2$ to $1: 10$ (Gutiérrez-Negrín, 1988; Sánchez-Díaz, 2007).

\section{Methods}

\subsection{Field and laboratory}

Water samples were collected from 40 production wells using standard protocols in March 2011 when, according to the climatology history of CONAGUA (2012), the season is dry. The samples were analyzed for major and minor ions ( $\mathrm{Na}$, $\mathrm{K}, \mathrm{Ca}, \mathrm{Mg}, \mathrm{Cl}, \mathrm{SO}_{4}, \mathrm{HCO}_{3}, \mathrm{SiO}_{2}$ ), trace elements ( $\mathrm{Sr}, \mathrm{F}$, $\left.\mathrm{Fe} \mathrm{Zn}, \mathrm{Li}, \mathrm{Mn}, \mathrm{Ba}, \mathrm{NO}_{3}-\mathrm{N}\right)$ and isotopes $\left(\delta^{2} \mathrm{H}, \delta^{18} \mathrm{O},{ }^{3} \mathrm{H}\right)$. Field parameters such as temperature, $\mathrm{pH}$, electrical conductivity (EC) and dissolved oxygen (DO) were measured using portable meters (Thermo, Orion). Alkalinity was determined in the field by volumetric titration $\left(0.02 \mathrm{~N} \mathrm{H}_{2} \mathrm{SO}_{4}\right)$ of filtered water samples to $\mathrm{pH}$ 4.3. At each sampling site, new and pre-rinsed low-density polyethylene bottles were filled with filtered $(0.45 \mu \mathrm{m})$ sample water. Cation and silica samples were acidified with ultrapure $\mathrm{HCl}$ to $\mathrm{pH}<2$, and all of the samples were stored in the laboratory at a constant temperature of $4^{\circ} \mathrm{C}$. Dissolved cations and anions were determined by inductive-coupled plasma mass spectrometry (ICP-MS) and ion chromatography, respectively. Duplicates of selected samples were analyzed using inductive-coupled plasma optical emission spectrometry (ICP-OES) and ion chromatography, following standard methods (APHA, 2012).

Stable water isotopes were analyzed at Environmental Isotope Laboratory, University of Waterloo, Canada. To conduct deuterium $\left({ }^{2} \mathrm{H}\right)$ analyses, sample water was reduced on hot manganese $\left(512^{\circ} \mathrm{C}\right)$ and the released hydrogen was analyzed by GC-MS. To conduct oxygen-18 $\left({ }^{18} \mathrm{O}\right)$ analyses, water was equilibrated with $\mathrm{CO}_{2}$. Preparation and extraction took place on a fully automated system vessel attached to a VG MM 903 mass spectrometer. The ${ }^{2} \mathrm{H}$ and ${ }^{18} \mathrm{O}$ results are reported as $\delta$ values with respect to the VSMOW (Vienna Standard Mean Ocean Water) standard. The analytical precision is $\pm 0.15 \%$ $\left(\delta^{18} \mathrm{O}\right)$ and $\pm 2 \%\left(\delta^{2} \mathrm{H}\right)$, respectively. Tritium $\left({ }^{3} \mathrm{H}\right)$ was analyzed at Environmental Isotope Laboratory, University of Arizona, using a liquid scintillation counter after electrolytic enrichment. The average analytical precision of tritium analyses was $\sim 0.3 \mathrm{TU}$.

\subsection{Techniques of analysis}

A preliminary description of water chemistry and identification of possible processes as water-rock interaction, mixing, evaporation, hydrothermal processes, anthropogenic contamination and transport of contaminants were performed using a correlation analysis. A hierarchical cluster analysis (HCA) organized samples into classified groups which were evaluated according to their geographic correspondence. A principal component analysis (PCA) elucidated the main controls 
on groundwater chemistry. All of the statistical calculations were performed using Minitab version 17.1 (Minitab, 2013).

The multivariate mixing and mass balance model, or M3 (Laaksoharju et al., 2008), was used to help to understand groundwater composition. The main aim of M3 is to differentiate between what is due to mixing and what is due to water-rock reactions. The M3 method compares the measured groundwater composition of each sample to the selected reference water and reports the changes in terms of mixing and reactions. A PCA is used to summarize the groundwater data by using the majority of the dissolved groundwater constituents $\mathrm{Ca}, \mathrm{Na}, \mathrm{Mg}, \mathrm{K}, \mathrm{Cl}, \mathrm{SO}_{4}$ and $\mathrm{HCO}_{3}$ in combination with the isotopes $\delta^{2} \mathrm{H}, \delta^{18} \mathrm{O}$ and ${ }^{3} \mathrm{H}$. The outcome of the analyses can be visualized as a scatter plot (PCA plot) for the first two principal components. The observations inside the polygon of the PCA plot are compared to the previously chosen reference water compositions. The mixing calculations create ideal mixing models that use linear distances of the samples from the selected reference waters in the PCA plot.

In this study, the following compositions of samples were used as reference waters: (i) three deep wells located in the La Primavera geothermic field, representing hydrothermal water; with data taken from Mahood (1983), Maciel-Flores (1992) and Prol-Ledesma (1995): well PP1 $\left(T=255^{\circ} \mathrm{C}, \quad \mathrm{Cl}=851 \mathrm{mg} \mathrm{L}^{-1}, \quad \mathrm{~B}=120 \mathrm{mg} \mathrm{L}^{-1}\right.$, $\mathrm{Li}=9.9 \mathrm{mg} \mathrm{L}^{-1}$ and $\left.\mathrm{Na}=\mathrm{mg} \mathrm{L}^{-1}\right)$, well PP2 $\left(T=265^{\circ} \mathrm{C}\right.$, $\mathrm{Cl}=1.120 \mathrm{mg} \mathrm{L}^{-1}, \quad \mathrm{~B}=131 \mathrm{mg} \mathrm{L}^{-1}, \quad \mathrm{Li}=8.5 \mathrm{mg} \mathrm{L}^{-1}$ and $\left.\mathrm{Na}=2000 \mathrm{mg} \mathrm{L}^{-1}\right)$ and well PP3 $\left(T=265^{\circ} \mathrm{C}\right.$, $\mathrm{Cl}=1.500 \mathrm{mg} \mathrm{L}^{-1}, \quad \mathrm{~B}=54 \mathrm{mg} \mathrm{L}^{-1}, \quad \mathrm{Li}=3.9 \mathrm{mg} \mathrm{L}^{-1}$ and $\mathrm{Na}=3310 \mathrm{mgL}^{-1}$ ); (ii) well AT37, representing local groundwater with low temperature and salinity (Table 1); (iii) well AT12 with low temperature and high salinity was taken as polluted reference water (Table 1). Although it is uncertain whether the selected reference waters are end members or close to being so, they were selected from the available data set. Well AT37 is an adequate candidate for local groundwater because it is located in the recharge area, showing little interaction with rocks. The three deep wells in La Primavera caldera are most probably also an appropriate selection of hydrothermal reference water because their temperatures are in the range of geothermic temperatures according to Verma et al. (2012).

Chloride mass balance was applied with the purpose of validation of the M3 modeling estimates. This method has been discussed and applied in similar environments (e.g., Han et al., 2010) and assumes that extracted groundwater is a mix of two end members (thermal and non-thermal) and that the $\mathrm{Cl}$ ion behaves conservatively, which means that it does not participate in any chemical reactions, even at high temperatures.

\section{Results and discussion}

Sánchez-Díaz (2007) used groundwater temperature and total dissolved solids as criteria to classify wells in hydrothermal water from Toluquilla, hydrothermal water from springs NE of Guadalajara, non-hydrothermal, local groundwater, and mixed groundwater with both hydrothermal water and local groundwater (Gutiérrez-Negrín, 1988; Maciel-Flores and Rosas-Elguera, 1992). Considering different sets of historical and new data, this classification is too subjective, especially in the lower TDS range. Furthermore, some inconsistencies between correlation results from different sampling campaigns show that the interpretation is not straightforward. The variation is because most of the sampled sites do not agree, considering the different sampling campaigns. Also, seasonal biases play a role. The $\mathrm{Mg}$ concentration, for example, decreases with increasing temperature as expected from hydrothermal fluids (Panichi and Gonfiantini, 1981); on the other hand, an increasing $\mathrm{Mg}$ trend at low temperatures is observed, indicating saline groundwater. Finally, it was not clear if there are different sources of hydrothermal or saline waters that affect the local groundwater. These complications motivated us to use multivariate techniques instead of commonly used scatter plots and criteria to divide samples into groups and interpret for potential factors/sources. Because the measured parameters varied considerably from study to study, only data from this study were considered for chemical characterization and multivariate analyses.

\subsection{Groundwater chemical characterization}

Table 1 shows the concentrations of measured groundwater chemical elements, field parameters and isotopic data, along with the hydrochemical classification. The classification of waters was performed with $\mathrm{HCA}$ using 20 variables $(\mathrm{pH}$, temperature, EC, DO, $\mathrm{Na}, \mathrm{K}, \mathrm{Ca}, \mathrm{Mg}, \mathrm{Cl}, \mathrm{HCO}_{3}, \mathrm{SO}_{4}, \mathrm{NO}_{3}$ $\left.\mathrm{N}, \mathrm{Sr}, \mathrm{Si}, \mathrm{Fe}, \mathrm{F}, \mathrm{Zn},{ }^{3} \mathrm{H},{ }^{2} \mathrm{H},{ }^{18} \mathrm{O}\right)$. With the help of Ward's linkage rule, iteratively neighboring points (samples) were linked through a similarity matrix (Ward, 1963). The squared Euclidian distance was selected as the similarity measurement. The second method was a PCA. For both cluster algorithms, log-normal distributed data were previously logtransformed, and all of the variables standardized ( $z$ scores). The HCA samples were classified into cold groundwater (CG), polluted groundwater (PG), mixed groundwater (MG) and hydrothermal groundwater $(\mathrm{HG})$, as represented by the dendrogram (Fig. 4) and median values (Table 2). The values for $\mathrm{Li}, \mathrm{Mn}$ and $\mathrm{Ba}$ were not considered in the cluster analysis, because most samples had concentrations below the detection limit.

The groundwaters are plotted on a Piper diagram to demonstrate chemical differences (Fig. 5). Salinity increases as groundwater moves east and southeastwards from La Primavera field to discharge areas along the topographic flow path. EC values typically reach $600 \mu \mathrm{S} \mathrm{cm}^{-1}$ in the discharge 


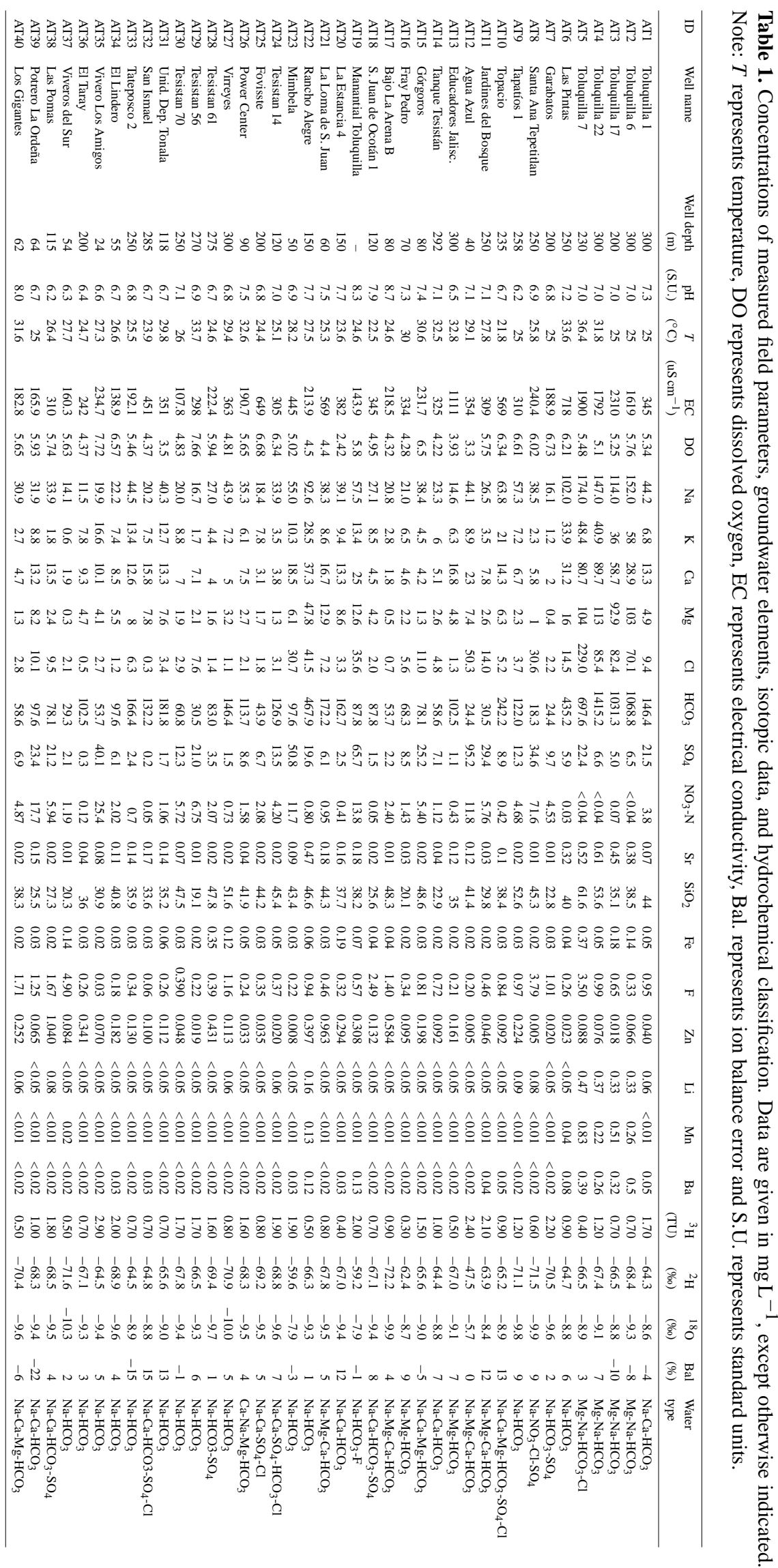




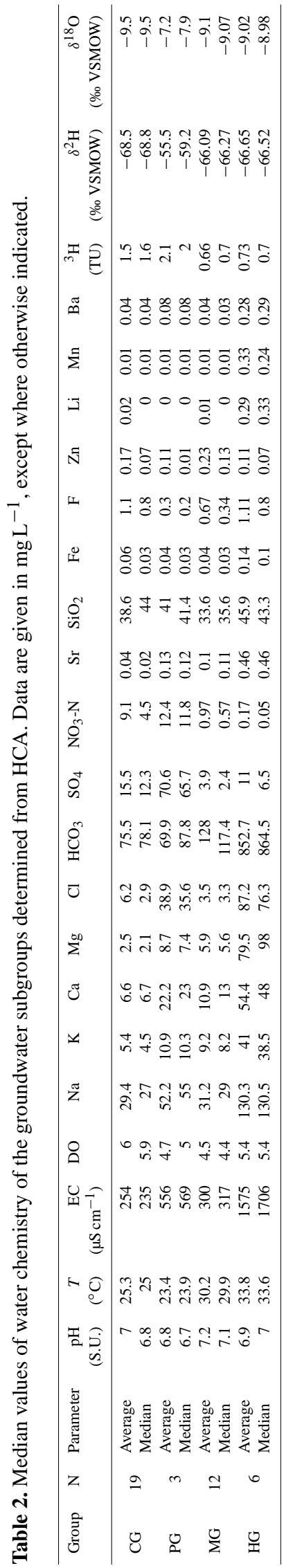

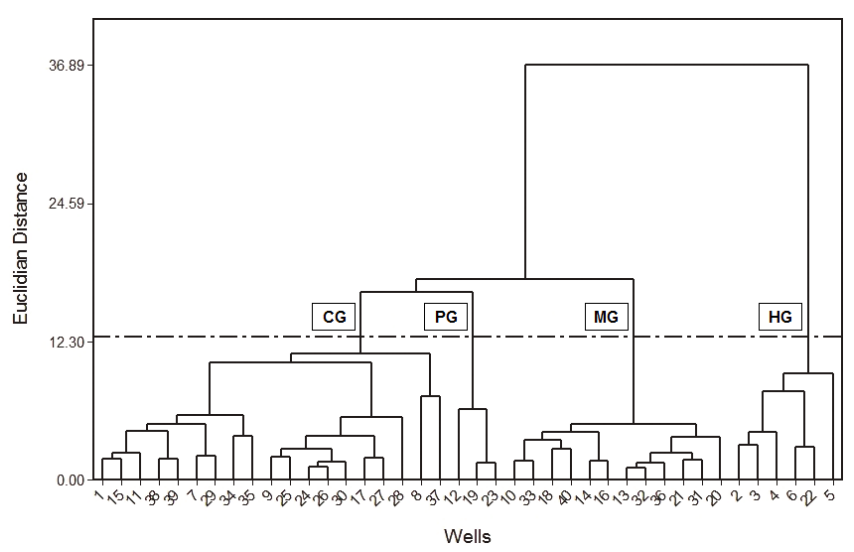

Figure 4. Dendrogram showing HCA classification with groups and subgroups of samples of the Atemajac-Toluquilla aquifer system. The dashed line indicates the "phenon line", an arbitrary line that defines subgroups.

areas of urbanized Guadalajara, except for Toluquilla wells where values ascend to $2300 \mu \mathrm{S} \mathrm{cm}^{-1}$. The CG $(n=19)$ is a $\mathrm{Na}-\mathrm{HCO}_{3}$ water type located in recharge zones in the western portion and reflects a short (local) groundwater flow path with poor circulation. It shows low temperatures (average $\left.25.3^{\circ} \mathrm{C}\right)$ and salinity $\left(254 \mu \mathrm{S} \mathrm{cm}^{-1}\right)$, however elevated $\mathrm{NO}_{3}-\mathrm{N}\left(9.1 \mathrm{mg} \mathrm{L}^{-1}\right)$ values, possibly derived from agricultural practices. Groundwater in the discharge area in central Guadalajara evolves to a $\mathrm{Na}-\mathrm{SO}_{4}$ to mixed- $\mathrm{HCO}_{3}$ water type (PG, $n=3$ ), with higher concentrations of several elements, indicating an important impact from anthropogenic pollution, i.e., $\mathrm{SO}_{4}\left(70.6 \mathrm{mg} \mathrm{L}^{-1}\right), \mathrm{NO}_{3}-\mathrm{N}\left(12.4 \mathrm{mg} \mathrm{L}^{-1}\right)$, $\mathrm{Na}\left(52.2 \mathrm{mg} \mathrm{L}^{-1}\right)$ and $\mathrm{Cl}\left(38.9 \mathrm{mg} \mathrm{L}^{-1}\right)$. Groundwater that moves in northern and eastern direction attains a $\mathrm{Na}$ $\mathrm{HCO}_{3}$ to mixed $\mathrm{HCO}_{3}$ water type (MG, $n=12$ ), with increased temperatures $\left(30.2^{\circ} \mathrm{C}\right)$ but similar low salinities $\left(300 \mu \mathrm{S} \mathrm{cm}^{-1}\right)$, indicating water-rock interactions. Finally, water that moves from the recharge zone at Primavera caldera southeast towards the central part of Toluquilla Valley attains a $\mathrm{Mg}-\mathrm{HCO}_{3}$ and mixed $\mathrm{HCO}_{3}$-type $(\mathrm{HG}, n=6)$. These wells show highest temperatures $\left(33.8^{\circ} \mathrm{C}\right)$ and salinity $\left(\mathrm{EC}=1.575 \mu \mathrm{S} \mathrm{cm}^{-1}\right)$, and lowest $\mathrm{NO}_{3}-\mathrm{N}\left(0.17 \mathrm{mg} \mathrm{L}^{-1}\right)$.

This preliminary evaluation of the evolution of groundwater chemistry along principal flow paths indicates that groundwater flow is affected by different sources. In the central and northern part of the study area, local groundwater from La Primavera caldera undergoes water-rock interactions and mixes with mountain-front recharge as well as return flow from agricultural plots and urban water cycling (Fig. 3, Sects. I and II), while in the southern portion, local water mixes with water from deeper formations that interacts with volcanic rocks of the La Primavera caldera and causes increased mineralization and temperatures (Fig. 3, Sects. I and II). 


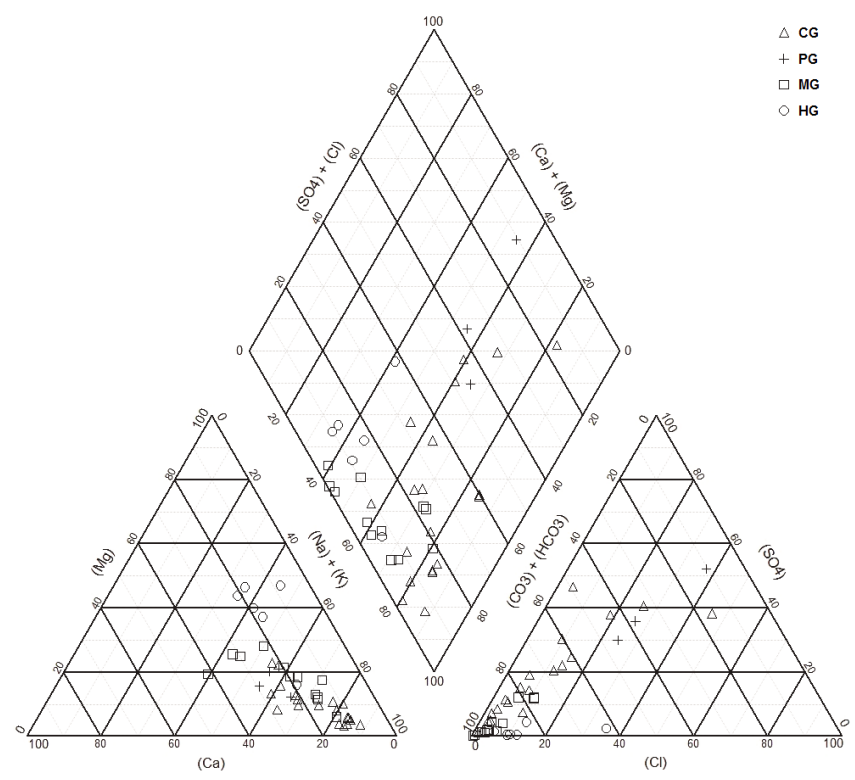

Figure 5. Piper diagram of groundwater samples from the Atemajac-Toluquilla aquifer system with well groups.

A factor analysis transformed the 20 variables into a reduced number of factors. The PCA, which loads most of the total variance onto one factor, was used in this study. The factors were extracted through the principal components method. Varimax rotation, where one factor explains mostly one variable, was selected. For fixing the maximum number of factors to be extracted, only factors with eigenvalues higher than 1 were taken into consideration (Kaiser normalization).

Table 3 shows that four factors may explain $77 \%$ of the variance. Factor 1 (PC1; $42 \%$ of the variance) largely represents high salinity. The correlations of temperature, $\mathrm{Na}$ and $\mathrm{Cl}$ indicate hydrothermal influence, while $\mathrm{HCO}_{3}, \mathrm{Na}$ and $\mathrm{Sr}$ could be connected to mineralization and rock dissolution processes, and cationic exchange. This factor is associated with $\mathrm{HG}$ and MG groups. In factor 2 (PC2; 17\%), the temperature is inversely related with $\mathrm{DO},{ }^{3} \mathrm{H}$, and to a lesser degree, $\mathrm{NO}_{3}$ and $\mathrm{SO}_{4}$, suggesting that this factor represents water affected by human activities, either urban or agricultural. In addition, Table 1 and Fig. 6 show that waters affected by human activities are mostly evaporated. Sulfate could be related to contamination due to the infiltration of commonly applied sulfate-based fertilizers during the rainy season. This occurs because all the wells are undersaturated with regard to gypsum, indicating that the water does not move through deposits of this mineral. This factor is associated with the PG group. In factor 3 (PC3; 11\%), the linear relationship between ${ }^{2} \mathrm{H}$ and ${ }^{18} \mathrm{O}$ reveals the existence of recharge water. This factor is related to the $\mathrm{CG}$ group. The relation with temperature indicates the recharge conditions at different recharge sites. Factor 4 (PC4; $7 \%$ ) may be indicative of the dissolution of minerals that contain F. The study of
Table 3. Rotated component matrix of the factor analysis for groundwater samples from the Atemajac-Toluquilla aquifer system. Coefficients between -0.1 and 0.1 are suppressed. Note: DO represents dissolved oxygen, $T$ represents temperature and EC represents electrical conductivity.

\begin{tabular}{lrrrr}
\hline Variable & PC1 & PC2 & PC3 & PC4 \\
\hline $\mathrm{pH}$ & & & & 0.47 \\
$T$ & 0.24 & 0.23 & 0.29 & \\
$\mathrm{EC}$ & 0.32 & & & \\
$\mathrm{DO}$ & & -0.25 & & \\
${ }^{3} \mathrm{H}$ & & -0.37 & & 0.15 \\
${ }^{2} \mathrm{H}$ & & & 0.45 & -0.20 \\
${ }^{18} \mathrm{O}_{\mathrm{HCO}}$ & & & 0.45 & \\
$\mathrm{~K}$ & 0.32 & & & \\
$\mathrm{Mg}$ & 0.32 & & & \\
$\mathrm{SiO}$ & 0.33 & & & \\
$\mathrm{Ca}$ & & & & -0.23 \\
$\mathrm{Fe}$ & 0.32 & & & \\
$\mathrm{Na}$ & & & & -0.37 \\
$\mathrm{Sr}$ & 0.33 & & & \\
$\mathrm{Zn}$ & 0.32 & & & 0.13 \\
$\mathrm{~F}$ & & & & \\
$\mathrm{Cl}$ & & & & -0.371 \\
$\mathrm{NO}$-N & 0.3 & & & \\
$\mathrm{SO}_{4}$ & & -0.40 & & \\
Eigenvalue & & & \\
$\%$ of variance & & & \\
$\mathrm{Cumulative} \mathrm{\%} \mathrm{variance}$ & 42 & 59 & 70 & 77 \\
\hline
\end{tabular}

Sánchez-Díaz (2007) indicates that rhyolitic rocks and ashes of the study area are responsible for releasing F. Comparable trends have been observed in various similar volcanic environments in central and northern Mexico (Mahlknecht et al., 2004a, 2008). This factor is associated with MG and HG groups.

\subsection{Isotope hydrology}

Data from this study and complementary data reported by other investigations (IMTA, 1992; GEOEX-SIAPA, 2003) are used to study the origin and evolution of water in the study area (Fig. 6a). The $\delta^{2} \mathrm{H}$ vs. $\delta^{18} \mathrm{O}$ graph shows that groundwater is of meteoric origin with variable evaporation and mixed with hydrothermal fluid. Although all studies show a similar trend, the data reported by IMTA (1992) registered heavier $\delta^{18} \mathrm{O}$ values that may be attributable to evaporation or hydrothermal influence. Similar $\delta^{18} \mathrm{O}$ values in thermal systems have been reported in other studies, e.g., El-Fiky (2009) and Stumpp et al. (2014), with $\delta^{18} \mathrm{O}$ values ranging from -6.7 to -5.6 and -4.8 to $+0.8 \%$, respectively. Hydrothermal groundwater collected in Toluquilla, has a narrow range of $\delta^{18} \mathrm{O}(-9.4$ to $-8.8 \%)$ and $\delta^{2} \mathrm{H}(-67$ to $-68 \%$ o) values. In general, they tend to fall slightly be- 
Table 4. Mixing proportions from the multivariate mixing and mass balance model, M3, using the following reference waters: deep wells PP1, PP2 and PP3 as a reference for hydrothermal fluids; no. AT12 as a reference for polluted water; and no. AT37 as a reference for fresh groundwater and hydrothermal mixing proportions based on $\mathrm{Cl}$ mass balance $(\mathrm{m}-\mathrm{b})$ calculations. Note: Avg represents the average obtained from calculation using the three different hydrothermal reference waters; SD represents standard deviation.

\begin{tabular}{|c|c|c|c|c|c|c|c|c|c|}
\hline \multirow[t]{3}{*}{ Well ID } & \multirow[t]{3}{*}{ Well group } & \multicolumn{6}{|c|}{ M3 calculations } & \multirow{2}{*}{\multicolumn{2}{|c|}{$\begin{array}{c}\mathrm{Cl} \text { m-b calculations } \\
\% \text { hydrothermal } \\
\text { water }\end{array}$}} \\
\hline & & \multicolumn{2}{|c|}{$\begin{array}{c}\% \text { fresh } \\
\text { groundwater }\end{array}$} & \multicolumn{2}{|c|}{$\begin{array}{l}\% \text { polluted } \\
\text { water }\end{array}$} & \multicolumn{2}{|c|}{$\begin{array}{c}\% \text { hydrothermal } \\
\text { water }\end{array}$} & & \\
\hline & & Avg & $\mathrm{SD}$ & Avg & $\mathrm{SD}$ & Avg & SD & Avg & SD \\
\hline 1 & $\mathrm{CG}$ & 66.3 & 0.0 & 33.7 & 0.0 & 0.0 & 0.0 & 0.7 & 0.2 \\
\hline 15 & CG & 73.4 & 0.0 & 26.6 & 0.0 & 0.0 & 0.0 & 0.8 & 0.2 \\
\hline 11 & $\mathrm{CG}$ & 63.0 & 0.0 & 36.8 & 0.0 & 0.2 & 0.1 & 1.1 & 0.2 \\
\hline 38 & CG & 84.8 & 0.0 & 15.2 & 0.0 & 0.0 & 0.0 & 0.7 & 0.2 \\
\hline 39 & $\mathrm{CG}$ & 82.9 & 0.0 & 16.7 & 0.0 & 0.3 & 0.0 & 0.7 & 0.2 \\
\hline 7 & CG & 89.7 & 0.0 & 10.1 & 0.0 & 0.2 & 0.0 & 0.0 & 0.0 \\
\hline 29 & CG & 78.4 & 0.0 & 21.4 & 0.0 & 0.2 & 0.0 & 0.5 & 0.1 \\
\hline 34 & CG & 86.7 & 0.0 & 13.3 & 0.0 & 0.0 & 0.0 & 0.0 & 0.0 \\
\hline 35 & $\mathrm{CG}$ & 75.8 & 0.0 & 24.2 & 0.0 & 0.0 & 0.0 & 0.1 & 0.0 \\
\hline 9 & CG & 93.1 & 0.0 & 6.6 & 0.0 & 0.3 & 0.0 & 0.1 & 0.0 \\
\hline 25 & $\mathrm{CG}$ & 85.9 & 0.1 & 13.8 & 0.0 & 0.4 & 0.1 & 0.0 & 0.0 \\
\hline 24 & $\mathrm{CG}$ & 86.5 & 0.0 & 13.5 & 0.0 & 0.1 & 0.0 & 0.1 & 0.0 \\
\hline 26 & $\mathrm{CG}$ & 84.1 & 0.1 & 15.5 & 0.0 & 0.4 & 0.1 & 0.0 & 0.0 \\
\hline 30 & $\mathrm{CG}$ & 82.3 & 0.0 & 17.7 & 0.0 & 0.0 & 0.0 & 0.1 & 0.0 \\
\hline 17 & $\mathrm{CG}$ & 96.2 & 0.0 & 3.3 & 0.0 & 0.5 & 0.0 & 0.0 & 0.0 \\
\hline 27 & $\mathrm{CG}$ & 95.2 & 0.0 & 4.8 & 0.0 & 0.0 & 0.0 & 0.0 & 0.0 \\
\hline 28 & CG & 88.4 & 0.0 & 11.1 & 0.0 & 0.5 & 0.0 & 0.0 & 0.0 \\
\hline 8 & CG & 93.8 & 0.2 & 4.5 & 0.0 & 1.7 & 0.3 & 2.6 & 0.6 \\
\hline 37 & CG & 100.0 & 0.0 & 0.0 & 0.0 & 0.0 & 0.0 & 0.0 & 0.0 \\
\hline 12 & PG & 0.0 & 0.0 & 100.0 & 0.0 & 0.0 & 0.0 & 4.4 & 1.0 \\
\hline 19 & PG & 48.2 & 0.0 & 51.8 & 0.0 & 0.0 & 0.0 & 3.1 & 0.7 \\
\hline 23 & PG & 48.8 & 0.0 & 51.0 & 0.0 & 0.1 & 0.0 & 2.6 & 0.6 \\
\hline 10 & MG & 71.1 & 0.1 & 28.5 & 0.0 & 0.4 & 0.1 & 0.3 & 0.1 \\
\hline 33 & MG & 69.5 & 0.1 & 29.8 & 0.0 & 0.7 & 0.1 & 0.4 & 0.1 \\
\hline 18 & $\mathrm{MG}$ & 80.3 & 0.1 & 19.0 & 0.0 & 0.7 & 0.1 & 0.0 & 0.0 \\
\hline 40 & $\mathrm{MG}$ & 89.0 & 0.0 & 10.2 & 0.0 & 0.8 & 0.0 & 0.1 & 0.0 \\
\hline 14 & MG & 68.3 & 0.1 & 31.2 & 0.0 & 0.6 & 0.1 & 0.2 & 0.1 \\
\hline 16 & MG & 62.6 & 0.1 & 36.1 & 0.0 & 1.2 & 0.1 & 0.3 & 0.1 \\
\hline 13 & MG & 76.1 & 0.1 & 22.5 & 0.0 & 1.4 & 0.1 & 0.0 & 0.0 \\
\hline 32 & MG & 69.0 & 0.1 & 30.4 & 0.0 & 0.7 & 0.1 & 0.0 & 0.0 \\
\hline 36 & MG & 78.9 & 0.1 & 20.1 & 0.0 & 1.1 & 0.1 & 0.0 & 0.0 \\
\hline 21 & $\mathrm{MG}$ & 82.7 & 0.0 & 16.5 & 0.0 & 0.9 & 0.0 & 0.5 & 0.1 \\
\hline 31 & MG & 72.3 & 0.1 & 26.4 & 0.0 & 1.3 & 0.1 & 0.1 & 0.0 \\
\hline 20 & MG & 80.4 & 0.1 & 19.3 & 0.0 & 0.3 & 0.1 & 0.1 & 0.0 \\
\hline 2 & HG & 78.1 & 0.6 & 17.0 & 0.1 & 4.9 & 0.7 & 6.2 & 1.4 \\
\hline 3 & $\mathrm{HG}$ & 68.1 & 0.7 & 26.4 & 0.1 & 5.5 & 0.7 & 7.3 & 1.7 \\
\hline 4 & $\mathrm{HG}$ & 73.6 & 0.7 & 21.3 & 0.1 & 5.1 & 0.8 & 7.6 & 1.7 \\
\hline 5 & $\mathrm{HG}$ & 63.1 & 2.0 & 24.4 & 0.2 & 12.5 & 2.2 & 20.6 & 4.8 \\
\hline 6 & $\mathrm{HG}$ & 67.7 & 0.0 & 30.4 & 0.0 & 1.9 & 0.0 & 1.1 & 0.3 \\
\hline 22 & $\mathrm{HG}$ & 75.6 & 0.3 & 21.4 & 0.0 & 3.0 & 0.3 & 3.6 & 0.8 \\
\hline
\end{tabular}

low and parallel to the RMWL (regional meteoric water line), which most likely represents precipitation of a different origin, i.e., from rainstorms coming from outside the basin limits (e.g., Mahlknecht et al., 2004b). These samples show isotopic depletion, indicating that recharge by meteoric water is low, as demonstrated by a deuterium excess that ranges from
4 to $8 \%$ with an average of $5.5 \%$ (Fig. 6b). On the other hand, it is possible that only a displacement of $\delta^{18} \mathrm{O}$ is occurring, which could correspond to a geothermal effect and mixing with meteoric waters (Giggenbach and Lyon, 1977; Herrera and Custodio, 2003). The increased $\mathrm{Cl}$ concentrations compared to other groups evidences mixture with hy- 

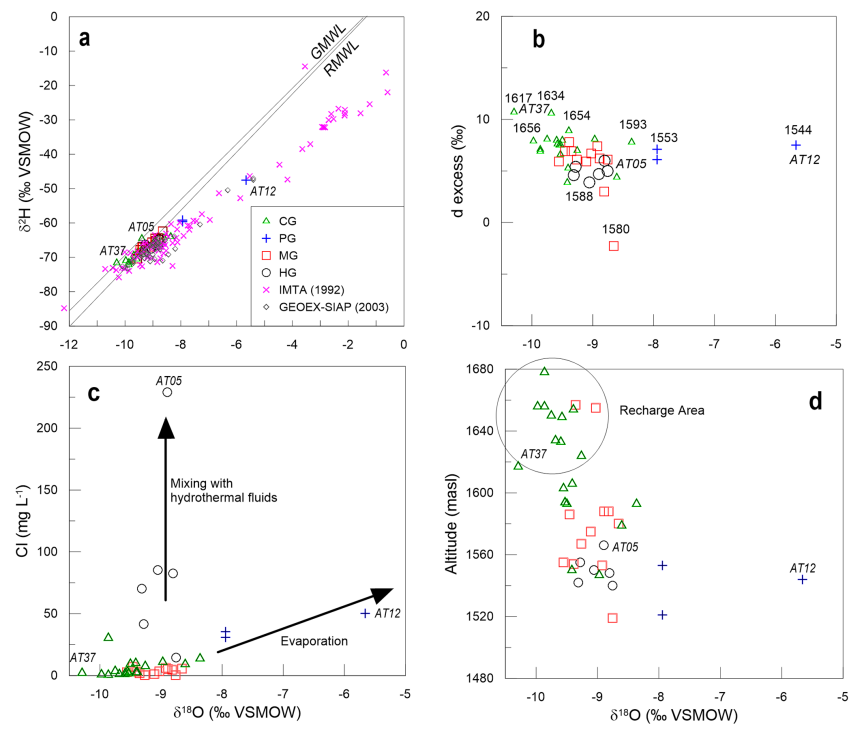

Figure 6. (a) Deuterium and oxygen-18 in groundwater from the Atemajac-Toluquilla aquifer system using well groups and results from previous studies; (b) oxygen-18 vs. deuterium excess with labeled altitudes; (c) oxygen-18 vs. chloride concentration; and (d) oxygen-18 vs. altitude. Note: GMWL represents the Global Meteoric Water Line (Rozanski et al., 1993); RMWL represents the regional meteoric water line (Wassenaar et al., 2009); IMTA represents Instituto Mexicano de Tecnología del Agua, GEOEX represents Geología y Exploraciones and SIAPA represents Sistema Intermunicipal para los Servicios de Agua Potable y Alcantarillado.

drothermal fluids and longer residence times (Fig. 6c). Mixed groundwaters, collected in the eastern and southern part of the ATAS, have $\delta^{18} \mathrm{O}$ and $\delta^{2} \mathrm{H}$ values ranging from -9.6 to $-8.6 \%$ and from -63 to $-71 \%$, respectively. These waters fall along the RMWL. Deuterium excess values vary between 5.3 and $8.1 \%$ with an average of $6.7 \%$. These values fall between $\mathrm{CG}$ and $\mathrm{HG}$, indicating the mixing of both (Fig. 6b), therefore, in accordance with the low concentration of $\mathrm{Cl}$, groundwater recharge is of meteoric origin (Fig. 6c). Polluted groundwaters (influenced by anthropogenic pollution) are quite different from the rest; they have heavier $\delta^{18} \mathrm{O}$ values ranging from -7.9 to $-5.7 \%$, and $\delta^{2} \mathrm{H}$ values varying from -59.6 to $-47.5 \%$, and are strongly affected by evaporation. Also a lower deuterium excess in the order of $+4 \%$ o is observed (Fig. 6b and c). The enriched outlier AT12 represents groundwater from a recreational park with lagoons. In this well there is a negative deuterium excess, indicating that rainwater presented evaporative diffusion processes in the soil during recharge process, possibly due to irrigation (Custodio, 1997; Manzano et al., 2001). Cold groundwater, mostly from the La Primavera recharge area, covers a relatively wide range of values compared to $\mathrm{HG}$ and MG. Their $\delta^{18} \mathrm{O}$ signatures vary from -10.3 to $-8.4 \%$, and their $\delta^{2} \mathrm{H}$ signatures from -72.2 to $-63.9 \%$. Deuterium excess in these wells is the highest and indicates preferential recharge between June and September (Jiménez-Martínez and Custodio, 2008; CONAGUA, 2012). The overlapping of HG, MG and CG groups indicates that aquifer formations are mostly hydraulically interconnected. Although altitude variations are in the order of only $400 \mathrm{~m}$ around La Primavera caldera, this seems to be enough to generate an altitude effect (Fig. 6d).

Tritium results indicate that groundwater within the study area includes both pre-modern (pre-1950s) and modern recharge. The values range from 0.3 to $3.0 \mathrm{TU}$, which suggests a contribution from modern water in most sampled sites. Hydrothermal groundwater and MG show less tritium activity in comparison to CG and PG (Table 2). Lowest values are in the order of analytical precision, thus eight samples may not contain modern water. Twenty-one samples considering $\mathrm{HG}$ and $\mathrm{MG}$ with ${ }^{3} \mathrm{H}$ lower than $1.0 \mathrm{TU}$ are in the southern portion of the aquifer system. Cold groundwater with elevated ${ }^{3} \mathrm{H}$ values (> $1.5 \mathrm{TU}$ ), located mostly in the $\mathrm{La}$ Primavera volcanic system, represent young waters or recent recharge with little mixing of path lines. Waters with ${ }^{3} \mathrm{H}$ values $<1.5 \mathrm{TU}$ illustrate that these wells may represent mixing of flow paths with modern and pre-modern groundwater residence times. These waters are found mostly in Toluquilla, referred to as hydrothermal groundwater, corresponding to elevated EC, $\mathrm{Cl}$ and DIC (dissolved inorganic carbon) values. The mixing of water from different ages is expectable because the aquifer is under unconfined conditions, while wells penetrate the saturated zone to a considerable depth, at times up to $500 \mathrm{~m}$, and are almost always completely screened.

\subsection{Mixing patterns}

Using a recommended permissible factor of 0.05 (Laaksoharju et al., 2009), all samples are located inside the cover area of the polygon of PCA plot (Fig. 7). The estimated mixing proportions are present in Table 4. Results indicate that the proportions of hydrothermal fluids are largest in the HG group varying from 1.9 to $12.5 \%$. The hydrothermal mixing proportions according to the $\mathrm{Cl}$ mass balance method were consistently higher, ranging from 6.2 to $20.6 \%$. Especially AT5 shows important differences between both methods. The other groups show hydrothermal fractions below $1.7 \%$ according to M3 modeling and $4.4 \%$ obtained from the $\mathrm{Cl}$ mass balance method. The PG group represents an insignificant share of hydrothermal water $(\sim 0 \%)$ due to the fact that these wells are located in recharge areas. On the other hand, this group shows an important proportion of anthropogenically impacted water $(>50 \%)$, while all other groups are less affected $(<37 \%)$.

These results validate the initial selection of groups based on cluster analysis: cold groundwater, polluted groundwater, mixed groundwater and hydrothermal groundwater. Geographically, groundwater with elevated hydrothermal proportions is located in the south to southeastern area (Toluquilla), and elevated proportions of polluted groundwater are located 

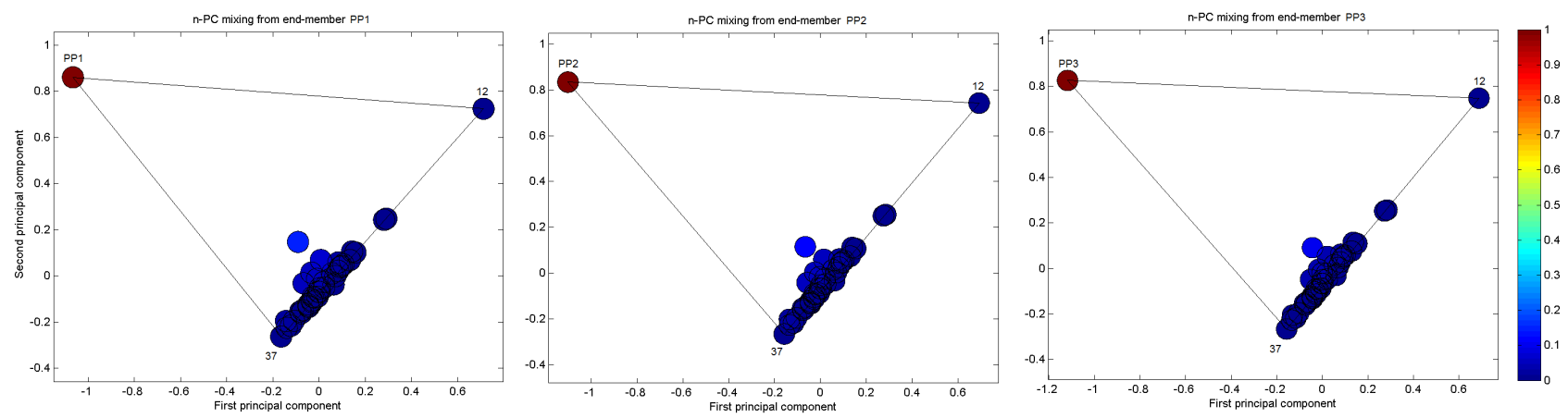

Figure 7. PCA plots of the M3 model from mixing of hydrothermal fluids with cold groundwater and polluted waters.

mostly in the urbanized area of Guadalajara. Hydrothermal fractions computed with the $\mathrm{Cl}$ mass balance method are general higher than those with M3 program, while for the polluted groundwater group there is no correspondence between methods. The differences between the two methods is not only due to the distinct underlying algorithm of both methods, but also due the fact that M3 modeling uses three reference waters and the $\mathrm{Cl}$ mass balance only two reference waters (thermal/non-thermal). However there is a generally high correlation between both methods $\left(r^{2}=0.87\right)$ which validates the results.

\subsection{Groundwater flow system of Guadalajara}

The hydrogeological Atemajac-Toluquilla system is located in the northeastern area of the Tepic-Zacoalco Rift, a complex and active neotectonic structure. Local groundwater recharge for Atemajac-Toluquilla Valley originates from rainfall mainly over the La Primavera caldera in the central western portion of the study unit. It flows from the upper alluvial sediments towards the valley floor and Santiago River. Recharge water is of Na-HCO3 water type with low temperatures, salinities, $\mathrm{Cl}$ and $\mathrm{Na}$ values, elevated $\mathrm{NO}_{3}$ concentrations, as well as relatively high tritium activities in the range of 0.5-2.9 TU, indicating little mixing of flow paths and recent recharge from pristine soils and return flow from agricultural plots, especially in Toluquilla Valley. This result confirms also a relatively fast transport through the unsaturated zone (Herrera and Custodio, 2014). As groundwater circulates in a northeastern (Atemajac Valley) and eastern direction (Guadalajara) following the hydraulic gradient, its temperature and salinity increases moderately. The wells are typically drilled in Tala Tuff underlain by andesites to basaltic andesite rocks. Locally, groundwater evolves to a $\mathrm{Na}-\mathrm{SO}_{4}$ to mixed $\mathrm{HCO}_{3}$ water type, with relatively high contents of $\mathrm{SO}_{4}, \mathrm{NO}_{3}, \mathrm{Na}, \mathrm{Cl}$ and tritium ( $\left.\sim 2 \mathrm{TU}\right)$, indicating an important impact of anthropogenic pollution in urban Guadalajara.

Underground heat flow suggests the existence of a magma chamber below the La Primavera caldera, which provides hydrothermal fluids observed on surface expressions such as the La Soledad Solfatara and the Cerritos Colorados geothermal field. Regional groundwater that is in contact with these fluids circulates through the lower Atemajac-Toluquilla aquifer, specifically below Santa Anita and Toluquilla locations. These $\mathrm{Mg}-\mathrm{HCO}_{3}$ to mixed $\mathrm{HCO}_{3}$ waters are characterized by elevated temperatures, salinity, $\mathrm{Cl}, \mathrm{Na}$ and $\mathrm{HCO}_{3}$ values and low tritium values $(<1.7 \mathrm{TU})$, and contain considerable concentrations of $\mathrm{Li}, \mathrm{Mn}, \mathrm{B}$ and $\mathrm{F}$, indicating thermal influence, circulation through an active volcanic center and fault zones and water-rock interactions. The corresponding wells are typically drilled in basalt-andesitic rock formations. The well depth of these wells range from 200 to $300 \mathrm{~m}$ and the depth-to-water table is about $50 \mathrm{~m}$. The low tritium concentration indicates pre-modern infiltration. Low tritium concentrations in deep wells, according to Herrera and Custodio (2014), are due to a mix of water from the upper aquifer and the vertical ascending flow from the lower aquifer. On the other hand, the tritium values show that geochemically speaking, the water predominates as an old fraction (Custodio, 1989). The isotopic composition of groundwater confirms the interconnectivity between water from deeper and shallow rock materials.

\section{Conclusions}

This work represents the first time that groundwater flow dynamics of Guadalajara region have been analyzed and characterized by using a suite of statistical and geochemical methods. Geochemical methods have been combined with multivariate statistical analysis and the multivariate mixing and mass balance model (M3) to determine the mixing patterns of different fluids when considering fresh groundwater, hydrothermal fluids and human-impacted waters. The mixing proportions have been compared to estimates from the chloride mass balance method.

The initial classification of groundwater groups by cluster analysis has been confirmed by water isotopic technologies, and identifying the controlling factors by principle component analysis is consistent with M3 modeling. The origin of groundwater recharge and the mixture of fresh groundwater with hydrothermal fluids and polluted water components 
was identified. A conceptual flow model was constructed for the Atemajac-Toluquilla aquifer system. The local flow is associated with the infiltration of rainwater that occurs at higher altitudes. Hydrothermal waters are probably related to recharge outside the study area and upward vertical flow in the La Primavera caldera and the valley of Toluquilla. TDS, $\mathrm{Cl}, \mathrm{Na}, \mathrm{Mn}$ and $\mathrm{Li}$ are most indicative of hydrothermal fluids. Modern water polluted with $\mathrm{SO}_{4}$ and $\mathrm{NO}_{3}$ can be associated with the infiltration of urban sewage and agricultural return flow. According to M3 modeling, the proportion of hydrothermal fluids within older waters was between $1.9 \%$ and $12.5 \%$, whereas it was lower than $1.7 \%$ within other waters. The proportion of polluted water in groundwater reached up to $52 \%$ in urbanized areas.

M3 is a powerful tool to evaluate the mixing proportions of selected reference waters present in aquifers. We recommend the use of the suite of traditional methods, environmental tracers, statistical analysis and M3 modeling in other aquifers with potentially multiple groundwater origins, especially in active volcanic systems where mixing is an important process. One limitation with this approach, however, is the representativeness of selected reference waters and samples. Part of this uncertainty may be overcome by repeating the field campaign considering seasonal/time variations.

These outcomes may help water authorities to identify wells with hydrothermal mixture or polluted water and act accordingly. The information regarding the proportions of fresh groundwater, hydrothermal fluids and polluted waters in each well indicates that the contaminants can be attributed to source waters. For example, $\mathrm{Li}, \mathrm{Mn}, \mathrm{Ba}, \mathrm{F}$ and $\mathrm{As}$ can be associated with hydrothermal fluids, and $\mathrm{SO}_{4}$ and $\mathrm{NO}_{3}$ are related to the production or use of fertilizers, dyes, glass, paper, soaps, textiles, fungicides or insecticides. These results helps authorities to decide whether certain wells have to be isolated or closed in order to provide Guadalajara with the required drinking water quality.

Acknowledgements. This work was financially supported by Fundación FEMSA and the Chair for Water Science and Technology (Tecnológico de Monterrey). Fundación FEMSA had no role in study design, data collection and analysis, decision to publish, or preparation of the manuscript. We would like to thank R. Ledesma and A. Mazón for technical assistance. The observations from E. Custodio, L. Stellato and two anonymous reviewers contributed to the improvement of the initially submitted manuscript.

Edited by: N. Romano

\section{References}

Ako, A. A., Eyong, G. E. T., Shimada, J., Koike, K., Hosono, T., Ichiyanagi, K., Akoachere, R., Tandia, B. K., Nkeng, G. E., and Ntankouo, N. R.: Nitrate contamination of groundwater in two areas of the Cameroon Volcanic Line (Banana Plain and Mount Cameroon area), Appl. Water Sci., 4, 99-113, 2013.

Aksoy, N., Simsek, C., and Gunduz, O.: Groundwater contamination mechanism in a geothermal field: a case study of Balcova, Turkey, J. Contam. Hydrol., 103, 13-28, 2009.

Alatorre-Zamora, M. A. and Campos-Enríquez J. O.: La Primavera Caldera (Mexico): Structure inferred from gravity and hydrogeological considerations, Geofis. Int., 31, 371-382, 1991.

Alva-Valdivia, R., Goguitchaichvili, A., Ferrari, L., RosasHelguera, J., Urrutia-Fucugauchi, J., and Zambrano-Orozco, J. J.: Paleomagnetic data from the Trans-Mexican Volcanic Belt: Implications for tectonics and volcanic stratigraphy, Earth Planets Space, 52, 467-478, 2000.

APHA.: Standard Methods for examination of water and wastewater, 22nd Edn., American Public Health Association, Washington, 2012.

Appelo, C. A. J. and Postma, D.: Geochemistry, groundwater and pollution, 2nd Edn., Leiden, the Netherlands, A.A. Balkema, 649 pp., 2005.

Bretzler, A., Osenbrück, K., Gloaguen, R., Ruprecht, J. S., Kebede, S. and Stadler, S.: Groundwater origin and flow dynamics in active rift systems e a multi-isotope approach in the Main Ethiopian Rift, J. Hydrol., 402, 274-289, 2011.

Campos-Enríquez, J. O. and Alatorre-Zamora, M. A.: Shallow crustal structure of the junction of the grabens of Chapala, TepicZacoalco and Colima, Mexico, Geofis. Int., 37, 263-282, 1998.

Campos-Enríquez, J. O., Domínguez-Méndez, F., Lozada-Zumaets, M., Morales-Rodríguez, H. F., and Andaverde-Arredondo, J. A.: Application of the Gauss theorem to the study of silicic calderas: the calders of La Primavera, Los Azufres, and Los Humeros (Mexico), J. Volcanol. Geoth. Res., 147, 39-67, 2005.

Chiodini, G., Marini, L., and Russo, M.: Geochemical evidence for the existence of high temperature hydrothermal brines at Vesuvio volcano, Italy, Geochim. Cosmochim. Ac., 65, 2129-2147, 2001.

Comisión Federal de Electricidad (CFE): Geotermia, Gerencia de Geotermia, 23 pp., 2000.

Comisión Nacional del Agua (CONAGUA): Determinación de la Disponibilidad de Agua en el Acuífero Toluquilla, Estado de Jalisco (Determination of Water Availability in the Toluquilla aquifer), Jalisco state, México, D.F., 2009.

Comisión Nacional del Agua (CONAGUA): Determinación de la Disponibilidad de Agua en el Acuífero Atemajac-Toluquilla, Estado de Jalisco (Determination of Water Availability in the Atemajac-Toluquilla aquifer), Jalisco state, México, D.F., 2010.

Comisión Nacional del Agua (CONAGUA): Climatología Estadística, Estado de Jalisco, México, D.F., 2012.

Custodio, E.: Groundwater characteristics and problems in volcanic rock terrains, Isotope Techniques in the Study of the Hydrology of Fractured and Fissured Rock, in: Proceedings of an Advisory Group Meeting, Vienna, Austria, 17-21 November, 87-137, 1989.

Custodio, E., Llamas, M. R., and Samper, J.: La evaluación de la recarga a los acuíferos en la planificación hidrológica, Asociación Internacional de Hidrogeólogos, Grupo Español-Instituto Tecnológico Geominero de España, 1997.

De Vries, J. J. and Simmers, I.: Groundwater recharge: an overview of processes and challenges, Hydrogeol. J., 10, 5-17, 2002.

Di Napoli, R., Aiuppa, A., Bellomo, S., Brusca, L., D’Alessandro, W., Gagliano Candela, E., Longo, M., Pecoriano, G., and 
Valenza, M.: A model for Ischia hydrothermal system: evidences from the chemistry of thermal groundwaters, J. Volcanol. Geoth. Res., 186, 133-159, 2009.

Di Napoli, R., Martorana, R., Orsi, G., Aiuppa, A., Camarda, M., De Gregorio, S., Gagliano Candela, E., Luzio, D., Messina, N., Pecoraino, G., Bitetto, M., de Vita, S., and Valenza, M.: The structure of a hydrothermal system from an integrated geochemical, geophysical and geology approach: The Ischia Island case study, Geochem. Geophy. Geosy., 12, 1-25, 2011.

Dogdu, M. S. and Bayari, C. S.: Environmental impact of geothermal fluids on surface water, groundwater and streambed sediments in the Akarcay Basin, Turkey, Environ. Geol., 47, 325340, 2005.

Edmunds, W. and Smedley, P.: Residence time indicators in groundwater: the East Midlands Triassic sandstone aquifer, Appl. Geochem., 15, 737-752, 2000.

El-Fiky, A.: Hydrogeochemistry and Geothermometry of Thermal Groundwater from the Gulf of Suez Region, J. King Abdulaziz Univ. Sci., Egypt, 20, 71-96, 2009.

Evans, W. C., Sorey, M. L., Cook, A. C., Kennedy, B. M., Shuster, D. L., Colvard, E. M., White, L. D., and Huebner, M. A.: Tracing and quantifying magmatic carbon discharge in cold groundwaters: lessons learned from Mammoth Mountain, USA, J. Volcanol. Geoth. Res., 114, 291-312, 2002.

Ferrari, L., Valencia-Moreno, M., and Bryan, S.: Magmatism and tectonics of the Sierra Madre Occidental and its relation with the evolution of the western margin of North America, in: Geology of México: Celebrating the Centenary of the Geological Society of México, edited by: Alaniz-Álvarez, S. A. and NietoSamaniego, A. F., Geol. Soc. Am., Special Paper, 422, 1-39, 2007.

Forrest, M. J., Kulongoski, J. T., Edwards, M. S., Farrar, C. D., Belitz, K., and Norris, R. D.: Hydrothermal contamination of public supply wells in Napa and Sonoma Valleys, California, Appl. Geochem., 33, 25-40, 2013.

Furi, W., Razack, M., Abiye, T. A., Kebede, S., and Legesse, D.: Hydrochemical characterization of complex volcanic aquifers in a continental rifted zone: the Middle Awash basin, Ethiopia, Hydrogeol. J., 20, 385-400, 2011.

GEOEX-SIAPA: Estudio geohidrológico Atemajac-Toluquilla, Sistema Intermunicipal de Agua Potable y Alcantarillado (SIAPA), Guadalajara, Jalisco, México, 2003.

Ghiglieri, G., Pittalis, D., Cerri, G., and Oggiano, G.: Hydrogeology and hydrogeochemistry of an alkaline volcanic area: the NE Mt. Meru slope (East African Rift - Northern Tanzania), Hydrol. Earth Syst. Sci., 16, 529-541, doi:10.5194/hess-16-5292012, 2012.

Giggenbach, W. F. and Lyon, G. L.: The chemical and isotopic composition of water and gas discharges from the Ngawha geothermal field, Northland, DSIR, Chem. Div. Report No: CD:30/555/7, 1977.

Goff, F. and Janik, C. J.: Geothermal systems, in: Encyclopedia of Volcanoes, edited by: Sigurdsson, H., Houghton, B., McNutt, S., Rymer, H., and Stix, J., Academic Press, San Diego, CA, 817834,2000

Gutiérrez-Negrín, L.: La Primavera, Jalisco, Mexico: geothermal field, Transactions of the Geothermal Research Council, 12, 161165,1988 .
Gutiérrez-Negrín, L. C. A.: Recursos Geotérmicos en La Primavera, Jalisco, Ciencia y Desarrollo, 16, 57-69, 1991.

Han, D. M., Liang, X., Jin, M. G., Currell, M. J., Song, X. F., and Liu, C. M.: Evaluation of groundwater hydrochemical characteristics and mixing behavior in the Daying and Qicun geothermal systems, Xinzhou Basin, J. Volcanol. Geoth. Res., 189, 92-104, 2010.

Henley, R. W. and Ellis, A. J.: Geothermal systems, ancient and modern: a geochemical review, Earth. Sci. Rev., 19, 1-50, 1983.

Herrera C. and Custodio, E.: Hipótesis sobre el origen de la salinidad de las aguas subterráneas en la isla de Fuerteventura, Archipiélago de Canarias, España, Bol. Geol. Min., 114, 433452, 2003.

Herrera, C. and Custodio, E.: Groundwater flow in a relatively old oceanic volcanic island: The Betancuria area, Fuerteventura Island, Canary Islands, Spain, Sci. Total Environ., 496, 531-550, 2014.

Hockstein, M. P. and Browne, P. R. L.: Surface manifestations of geothermal systems with volcanic heat sources, in: Encyclopedia of Volcanoes, edited by: Sigurdsson, H., Houghton, B., McNutt, S., Rymer, H., and Stix, J., Academic Press, San Diego, CA, 835856, 2000.

Instituto Mexicano de Tecnología del Agua (IMTA): Estudio isotópico e hidroquímico de los acuíferos de Toluquilla-OcotlánLa Barca, en el estado de Jalisco, Informe técnico, Instituto Mexicano de Tecnología del Agua, Jiutepec, Morelos, Mexico, 1992.

Jiménez-Martínez, J. and Custodio E.: El exceso de deuterio en la lluvia y en la recarga a los acuíferos en el área circummediterránea y en la costa mediterránea española, Boletín Geológico y Minero, 119, 21-32, 2008.

Köppen, W.: Das geographische System der Klimate, in: Handbuch der Klimatologie, Herausgeber: Köppen, W. and Geiger, G., 1. C., Gebr. Borntraeger, Berlin, 1-44, 1936.

Laaksoharju, M., Smellie, J., Tullborg, E.-L., Gimeno, M., Molinero, J., Gurban, I., and Hallbeck, L.: Hydrogeochemical evaluation and modelling performed within the site investigation programme, Appl. Geochem., 23, 1761-1795, 2008.

Laaksoharju, M., Skårman, E., Gómez, J. B., and Gurban, I.: M3 version 3: user's manual, SKB TR-09-09, Stockholm, Sweden, Svensk Kärnbränslehantering AB, 2009.

Maciel-Flores, R. and Rosas-Elguera, J.: Modelo geológico y evaluación del campo geotérmico La Primavera, Jal, México, Geofís. Int., 31, 359-370, 1992.

Mahlknecht, J., Schneider, J. F., Merkel, B. J., de Leon, I. N., and Bernasconi S. M.: Groundwater recharge in a sedimentary basin in semi-arid Mexico, Hydrogeol. J., 12, 511-530, 2004a.

Mahlknecht, J., Steinich, B., and Navarro de León, I.: Groundwater chemistry and mass transfers in the Independence aquifer, central Mexico, by using multivariate statistics and mass-balance models, Environ. Geol., 45, 781-795, 2004b.

Mahlknecht, J., Horst, A., Hernández-Limón, G., and Aravena, R.: Groundwater geochemistry of the Chihuahua City region in the Rio Conchos Basin (Northern Mexico) and implications for water resources Management, Hydrol. Process., 22, 4736-4751, 2008.

Mahood, G. A., Truesdell, A. H., and Templos M. L. A.: A reconnaissance geochemical study of La Primavera geothermal area, Jalisco, Mexico, J. Volcanol. Geoth. Res., 16, 247-261, 1983. 
Manzano, M., Custodio, E., Loosli, H., Cabrera, M. C., Riera, X., and Custodio, J.: Palaeowater in coastal aquifers of Spain, in: Palaeowaters in Coastal Europe: Evolution of Groundwater since the Late Pleistocene, edited by: Edmunds, W. M. and Milne, C. J., Geological Society of London, Special Publication, Hampshire, UK, 189, 107-138, 2001.

Michaud, F., Gasse, F., Bourgois, J., and Quintero, O.: Tectonic controls on lake distribution in the Jalisco Block area (western Mexico) from Pliocene to Present, in: Cenozoic Tectonics and Volcanism of Mexico, edited by: Delgado-Granados, H., AguirreDíaz, G. J., and Stock, J. M., Geol. Soc. Am., Boulder, CO, Special paper, 334, 99-110, 2000.

Minitab: Statistical Software (version 17.1), Minitab Inc., State College, PA, 2013.

Navarro, A., Font, X., and Viladevall, M.: Geochemistry and groundwater contamination in the La Selva geothermal system (Girona, Northeast Spain), Geothermics, 40, 275-285, 2011.

Panichi, C. and Gonfiantini, R.: Geothermal waters, in: Stable Isotope Hydrology, edited by: Gat, J. R. and Gonfiantini, R., IAEA Tech. Rep. Ser., 241-272, 1981.

Panno, S. V., Hackley, K. C., Locke, R. A., Krapac, I. G., Wimmer, B., Iranmanesh, A., and Kelly, W. R.: Formation waters from Cambrian-age strata, Illinois Basin, USA: Constraints on their origin and evolution based on halide composition, Geochim. Cosmochim. Ac., 122, 184-197, 2013.

Prol-Ledesma, R. M., Hernandez-Lombardini, S. I., and LozanoSanta Cruz, R.: Chemical variations in the rocks of La Primavera geothermal field (Mexico) related with hydrothermal alteration, in: Proceedings of the 17th NZ Geothermal Workshop, Auckland, New Zealand, 8-10 November 1995, 47-53, 1995.

Ramírez, S. G., Casco del Razo, J., and Mata, V. V. M.: Hidrología regional de la zona geotérmica de la Primavera-San MarcosHervores de la Vega, Jal, Informe técnico (inédito), Comisión Federal de Electricidad, 1982.

Reimann, C., Bjorvatn, K., Frengstad, B., Melaku, Z., TekleHaimanot, R., and Siewers, U.: Drinking water quality in the Ethiopian section of the East African Rift Valley I - data and health aspects, Sci. Total. Environ., 311, 65-80, 2003.

Rozanski, K., Araguás-Araguás, L., and Gonfiantini, R.: Isotopic patters in modern global precipitation, in: Climate Change in Continental Isotopic Records, edited by: Swart, P. K., Lohmann, K. C., McKenzie, J., and Savin, S., American Geophysical Union, doi:10.1029/GM078p0001, 1993.

Sánchez-Díaz, L. F.: Origen, transporte, distribución y concentraciones de los fluoruros en el sistema hidrogeológico volcánico Atemajac-Toluquilla, Jalisco, México, PhD thesis, Universidad Nacional Autónoma de México, México, D. F., 128 pp., 2007.
Siebert, C., Rosenthal, E., Möller, P., Rödiger, T., and Meiler, M.: The hydrochemical identification of groundwater flowing to the Bet She' an-Harod multiaquifer system (Lower Jordan Valley) by rare earth elements, yttrium, stable isotopes $(\mathrm{H}, \mathrm{O})$ and Tritium, Appl. Geochem., 27, 703-714, 2012.

Stumpp, C., Ekdal, A., Gönenc, I. E., and Maloszewski, P.: Hydrological dynamics of water sources in a Mediterranean lagoon, Hydrol. Earth Syst. Sci., 18, 4825-4837, doi:10.5194/hess-184825-2014, 2014.

Urrutia F. J., Alva-Valdivia, L. M., Rosas-Elguera, J., CamposEnriquez, O., Goguitchaichvili, A., Soler-Arechalde, A. M., Caballero-Miranda, C., Venegas Salgado, S., and SanchezReyes, S.: Magnetostratigraphy of the volcanic sequence of Río Grande de Santiago-Sierra de la Primavera region, Jalisco, western Mexico, Geofis. Int., 39, 247-265, 2000.

Valencia, V. A., Righter, K., Rosas-Elguera, J., Lopez-Martinez, M., and Grove, M.: The age and composition of the pre-Cenozoic basement of the Jalisco Block: implications for and relation to the Guerrero composite terrane, Contrib. Mineral. Petr., 166, 801824, 2013.

Venegas, S., Herrera, J. J., and Maciel, F. R.: Algunas características de la Faja Volcánica Mexicana y de sus recursos geotérmicos, Geofis. Int., 24, 47-83, 1985.

Venegas, S. S., Ramírez, S. G., Romero, G. C., Reyes, V. P., Razo, M. A., Gutiérrez, N. L. C. A., Arellano, G. F., and Rerezyera, Z. J.: La Primavera geothermal field, Jalisco, in: The Geology of North America, edited by: Salas, G. P., Economic Geology, Mexico, The Geological Society of America, 1991.

Verma, S. P., Arredondo-Parra, U. C., Andaverde, J., Gómez-Arias, E., and Guerrero-Martínez, F. J.: Three-dimensional temperature field simulation of a cooling of a magma chamber, La Primavera caldera, Jalisco, Mexico, Int. Geol. Rev., 54, 833-843, 2012.

Ward, J. H.: Hierarchical grouping to optimize an objective function, J. Am. Stat. Assoc., 58, 236-244, 1963.

Wassenaar, L. I., Van Wilgenburg, S. L., Larson, K., and Hobson, K. A.: A groundwater isoscape $\left(\delta \mathrm{D}, \delta^{18} \mathrm{O}\right)$ for Mexico, J. Geochem. Explor., 102, 123-136, 2009.

Williams, A. J., Crossey, L. J., Karlstrom, K. E., Newell, D., Person, M., and Woolsey, E.: Hydrogeochemistry of the Middle Rio Grande aquifer system - Fluid mixing and salinization of the Rio Grande due to fault inputs, Chem. Geol., 351, 281-298, 2013.

Zárate-del Valle, P. F. and Simoneit, B. R. T.: La generación de petróleo hidrotermal en sedimentos del Lago Chapala y su relación con la actividad geotérmica del rift Citala en el estado de Jalisco, Rev. Mex. Cienc. Geol., 22, 358-370, 2005. 